\title{
The Effect of Mercury Exposure to Escherichia Coli Bacteria Resistant to Mercury and Escerichia Coli Esbl in Vitro
}

\author{
Diah Retno Kusumawati
}

Clinical Medical Science Master Degree, Faculty of Medicine Airlangga University Surabaya

Corresponding author: diahrtno@gmail.com

\begin{tabular}{l}
\hline ARTICLE INFO \\
\hline Keywords: \\
Escherichia coli, \\
sensitive, resistant, \\
mercury, ESBL
\end{tabular}

Submission: June 4th, 2021

Review:

June 4th, 2021

Publish:

July 25th, 2021

\begin{abstract}
Background: The level of pollution in Indonesia is still very high, consist of water pollution, air pollution and soil pollution. Mercury is one of the heavy metals that pollutes the waters of the sea, while Escherichia coli is exposed to mercury will try to defend itself by doing mercury detoxification so that it can live in an environment that contains mercury. Escherichia coli that tries to defend itself from mercury exposure in the environment will experience a change in its genes into mercury resistant Escherichia coli. In plasmids or transposons, it might also stimulate the formation of resistance genes for some antibiotics, include producing the ESBL enzyme, so that it can convert non ESBL Escherichia coli into ESBL Escherichia coli. Objective: This study aims to prove that the repeated exposure of mercury will change non ESBL-mercury sensitive Escherichia coli into ESBL- mercury resistant Escherichia coli. Method: This was an experimental study with 27 non-ESBL Escherichia coli isolates as identified from Phoenix. Non-ESBL Escherichia coli clinical isolates were tested by giving exposure to $\mathrm{HgCl} 2$ with concentrations of 0.02 ppm, $0.10 \mathrm{ppm}, 0.20 \mathrm{ppm}$ for 1-14 days until mercury resistant Escherichia coli was formed, and then ESBL screening was tested by giving Cefotaxime exposure to them. Results: On the first day of mercury exposure, there were 9 isolates of $0.02 \mathrm{ppm}$ $\mathrm{HgCl} 2$ resistant Escherichia coli, 9 isolates of $0.10 \mathrm{ppm} \mathrm{HgCl} 2$ resistant Escherichia coli, 9 isolates of $0.20 \mathrm{ppm} \mathrm{HgCl} 2$ resistant Escherichia coli. Furthermore, this Escherichia coli isolate was exposed to Cefotaxim as ESBL screening. The final results of post-exposure $\mathrm{HgCl} 20.02$ ppm was obtained $3(33.3 \%)$ isolates were still sensitive to Cefotaxime and $6(66.7 \%)$ isolates that were resistant to Cefotaxime. The final results of post-exposure $\mathrm{HgCl} 20.10$ ppm was obtained all $9(100 \%)$ isolates that were resistant to Cefotaxime. The final results of post-exposure $\mathrm{HgCl} 20.20 \mathrm{ppm}$ obtained $2(22.2 \%)$ isolates were still sensitive to Cefotaxime and 7 (77.8\%) isolate were resistant to Cefotaxime. Conclusion: Escherichia coli in urine had the phenotive change into mercury resistant Escherichia coli. Mercury exposure of 0.02 ppm, $0.10 \mathrm{ppm}, 0.20 \mathrm{ppm}$ for 1 day in vitro on isolates of non ESBL-mercury resistant Escherichia coli caused changes in 22 isolates of Escherichia coli in urine.
\end{abstract}

\section{Introduction}

The level of pollution in Indonesia is still very high in the form of water, air, and soil pollution. This pollution will be a serious threat to the Indonesian state with all its potential. Humans can be exposed to mercury not only from environmental pollution but can also be caused by the use of cosmetic ingredients containing mercury, consuming food/drinks containing mercury, or due to direct contact with materials containing mercury (Saraswati and Fahruddin, 2012) 
One of these wastes is that heavy metals can be sourced from factories or industries. The toxic and dangerous properties of heavy metals are shown by the physical and chemical properties of the material, both in terms of quality and quantity. Mercury is a heavy metal that pollutes marine waters, caused by natural factors and human activities that dispose of its waste into the waters. Sources of mercury waste can come from the cosmetics industry, electronics, paint manufacturing industry, denture manufacturing, gold smelting, as a catalyst, and others (Palar, 2008).

Several researchers have researched the presence of antibiotic-resistant bacteria coexisting in mercury-resistant bacteria. One of the studies that have been carried out in the research that has been conducted by Ririn (2013) from the Biology Department, Faculty of Mathematics and Natural Sciences, Hasanuddin University, Makassar. In her research, the isolation of bacteria from seawater samples from Losari Beach was carried out using Nutrient Media for Synthetic Sea Water Agar (NA ALS) added with $\mathrm{HgCl}$ with a concentration level of $0.0002 \mathrm{mg} / \mathrm{ml}(0.02 \mu \mathrm{g} / \mathrm{ml})$. Then the bacterial isolates were tested for antibiotic resistance using antibiotic paper disks (Oxoid) including Ampicillin 10 $\mu$ g,

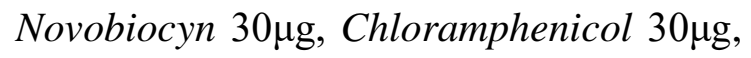
Cefoperazone $75 \mu \mathrm{g}$, and Ofloxacin $5 \mu \mathrm{g}$. Three types of isolates are mercury $(\mathrm{Hg})$ resistant and the antibiotics obtained are: mercury I resistant bacteria isolates which are also resistant to Ofloxacin $5 \mu \mathrm{g}$, mercury II resistant bacteria isolates that are resistant to Ampicillin $10 \mu \mathrm{g}$ and mercury III resistant bacteria isolate that is resistant to all types of antibiotics (Ririn, 2013).

Bacteria exposed to mercury will try to defend themselves by detoxifying mercury, so that these bacteria can live in environments that contain mercury. Bacteria that try to defend themselves from exposure to mercury in the environment will experience a change in their genes to become mercury-resistant bacteria. Mercury detoxification by mercuryresistant bacteria occurs because bacteria have the mer operon gene (Boyd, 2012).

The structure of the operon mer is different for each type of bacteria. Generally, the operon mer structure consists of the metalloregulator gene (merR), the mercury transfer gene (merT, merP, merC), the mercury reductase gene (merA), and the organo mercury lyase (merB). Bacteria that only have the mercury reductase (merA) gene are called narrow spectrum mercuryresistant bacteria. Several bacteria have in addition to the merA gene, also the merB gene, so these bacteria are called broadspectrum mercury resistant bacteria. The protein merA gene is responsible for the presence of the enzyme mercury reductase. The mercury reductase enzyme will give 2 electrons to NADPH or NADP so $\mathrm{Hg} 2+$ turns into $\mathrm{Hg} 0$ which is volatile and will be removed from the cell, while the MerB protein has the function of catalyzing the breaking of the mercury-carbon bond so that organic compounds and $\mathrm{Hg} 2+$ ions are produced. (Barkay et al., 2003).

In plasmids or transposons, it may also stimulate the formation of genes coding for resistance to several antibiotics, one of which is the enzyme-producing bacteria ESBL, where ESBL is mostly derived from the TEM and SHV enzymes, and in lesser amounts than CTX (Walker, 2015) where the ESBL coding gene can be either chromosomal or plasmidal. Changes in $E$. coli were initially sensitive to mercury without ESBL, but because they live in an environment that has high mercury levels, it can change to ESBL mercury-resistant $E$. 
coli. This is what makes researchers feel the need to do this research because with a large amount of mercury that is in nature, both in the environment, including air, soil, water, besides that there are animals that have been contaminated with mercury that we consume, many of the items we use are used. contains mercury ranging from cosmetics, medical equipment, factories, etc. and if we are exposed to these items then we will be contaminated with the mercury material and then the mercury levels in our bodies will be high. If there are bacteria that enter our bodies, then there is a possibility that bacteria are initially sensitive to non-ESBL mercury will become resistant to ESBL mercury, which is very dangerous for us and complicates the treatment.

In this study, the researchers researched bacteria that were resistant to mercury $(\mathrm{Hg})$ and ESBL whose isolates were taken from urine specimens at the Clinical Microbiology Unit of Dr. Soetomo Hospital, Surabaya.

\section{Methods}

This research is an experimental study, by providing treatment and observation of the results of urine culture that grows mercury susceptible non-ESBL E. coli bacteria. The E. coli strain is a clinical urine isolate stored in the Clinical Microbiology
Unit of the Dr. Soetomo Hospital, Surabaya.

The study population was clinical isolates of $E$. coli stored from urine specimens in the Clinical Microbiology Unit of Dr. Soetomo Hospital, Surabaya. The sample of this study was clinical isolate E. coli non ESBL stored from urine specimens in the Clinical Microbiology Unit of Dr. Soetomo Hospital, Surabaya. ppm to non-ESBL $E$. coli bacteria for 1-14 days.

The number of samples needed in this study is:

$$
\begin{aligned}
& (\mathrm{r}-1)(\mathrm{t}-1) \geq 15 \\
& (\mathrm{r}-1)(3-1) \geq 15 \\
& (\mathrm{r}-1)(2)) \geq 15 \\
& (\mathrm{r}-1) \geq 3 \\
& \quad \mathrm{r} \quad \sim 9 \\
& \text { Information } \\
& \mathrm{r}=\text { total samples } \\
& \mathrm{t}=\text { total treatment }
\end{aligned}
$$

So this study used 9 isolates of $E$. coli susceptible mercury non ESBL.

\section{The Sample's Criteria}

Inclusion criteria: E. coli comes from urine specimens in the Clinical Microbiology Unit of Dr. Soetomo Hospital and the E. coli isolate was not ESBL E. coli based on the identification and sensitivity testing with Phoenix or Vitex 2. Exclusion

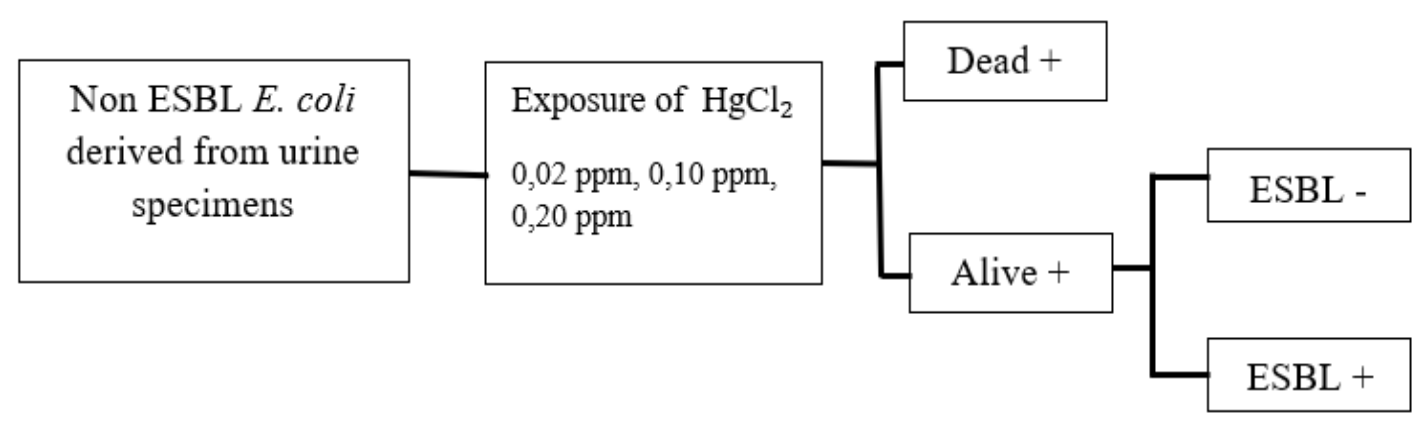

Figure 1. Research Diagram 
criteria: stored E. coli isolates that do not grow.

\section{Sampling Technique}

A sampling of stored clinical E. coli isolates from urine specimens in the Clinical Microbiology Unit, was carried out using consecutive sampling techniques. Each sample that meets the research criteria is taken for the required sample size.

\section{Research Variables And Operational Definitions}

\section{Research Variables}

1. Independent Variables: Repeated exposure of $\mathrm{HgCl}_{2}$ in $0,02 \mathrm{ppm}, 0,10$ ppm, and 0,20 ppm for 1 - 14 days

2. Dependent Variables: Occurence of E.coli resistence Mercury and which categorized as ESBL produce

The research was conducted at the Clinical Microbiology Unit of Dr. Soetomo Hospital, Surabaya. From May 2019 August 2019. The main material used in this study was clinical isolates of E. coli bacteria non ESBL stored from urine specimens in the Clinical Microbiology Unit Dr. Soetomo Surabaya. Additional materials used in this study were Mueller-Hinton agar, $\mathrm{HgCl}_{2}$ liquid with a concentration of 0.02 ppm, 0.10 ppm, 0.20 ppm, 30 $\mu \mathrm{g}$ Cefotaxime antibiotic disk.

\section{Difusion Method}

\section{The Techniques That Used In}

\section{Laboratory}

1. The media was used is MHA (MuellerHilton Agar)

2. Empty disc which dropped by $\mathrm{HgCl}_{2}$ liquid with 0,02 ppm, 0,10 ppm, and 0,20 ppm consentration

\section{The Procedure:}

1. Do the streaking of the bacteria that will be tested on all surfaces so that they are evenly distributed.

2. Place an empty disc dripped with liquid $\mathrm{HgCl}$ with a concentration of $0.02 \mathrm{ppm}$, $0.10 \mathrm{ppm}, 0.20 \mathrm{ppm}$ on the agar surface.

3. Plate $9-10 \mathrm{~cm}$ in diameter.

4. Furthermore, the plates were incubated at $35^{\circ} \mathrm{C}$ for 24 hours.

5 . The zone diameter is measured in $\mathrm{mm}$.

The Interpretation Result Of Treatmented $E$. coli

1. Susceptible (S)

The tested isolate can be inhibited with this antimicrobial at the recommended dosage. It is said to be susceptible if an inhibition zone is obtained.

2. Resistance $(\mathrm{R})$

This means that isolates cannot be inhibited by these antimicrobials. It is said to be resistant if an inhibition zone is not found.

\section{Research Work Procedure}

\section{Mercury Disc Preparation}

a. $\mathrm{HgCl}_{2}$ disc $0,02 \mathrm{ppm}$ consentration is a mercury which diluted with $\mathrm{Cl}_{2}$.

b. $\mathrm{HgCl}_{2}$ disc $0,10 \mathrm{ppm}$ consentration is a mercury which diluted with $\mathrm{Cl}_{2}$.

c. $\mathrm{HgCl}_{2}$ disc $0,20 \mathrm{ppm}$ consentration is a mercury which diluted with $\mathrm{Cl}_{2}$.

\section{Bacteria Isolate Preparation}

1. E. coli isolates stored from urine specimens in the Clinical Microbiology Unit have been identified and tested for antibiotic sensitivity.

2. Isolates that met the criteria as E. coli bacteria and the degree of sensitivity to Cefotaxime, Ceftazidime, Ceftriaxone, and Aztreonam (Phoenix-BD, CLSI M100-S 2019) were selected 3 - 5 colonies from MacConkey agar media using cotton stick swabs. 
3. Then it is suspended in a $0.9 \% \mathrm{NaCl}$ solution in a glass tube until it reaches a germ density of $0.5 \mathrm{McFarland}$ which is equivalent to $1.5 \times 108 \mathrm{CFU} / \mathrm{mL}$.

\section{Hg Disc and Cefotaxime Preparation}

1. The 0.5 McFarland suspension was densely planted onto the MHA surface. Placed the disc which already dripped by $\mathrm{HgCl}_{2}$ with $0,02 \mathrm{ppm}, 0,10 \mathrm{ppm}$, and $0,20 \mathrm{ppm}$ consentration in the surface of MHA.

2. MHA plates were incubated for $18-24$ hours at $35^{\circ} \mathrm{C} \pm 2{ }^{\circ} \mathrm{C}$.

\section{Isolate Preparation for 2 Days of Exposure and Later}

1. Colonies that are on the edge of the inhibition zone are taken with a sterile cotton swab

2. Then it was suspended in a $0.9 \% \mathrm{NaCl}$ solution to reach 0.5 McFarland turbidity.

3. The 0.5 McFarland suspension was densely planted onto the MHA surface. On the surface of the MHA, a disc that has been dripped with $\mathrm{HgCl}$ is placed with a concentration of $0.02 \mathrm{ppm}, 0.10$ ppm, 0.20 ppm

4. MHA plates were incubated for 18-24 hours at $35^{\circ} \mathrm{C} \pm 2{ }^{\circ} \mathrm{C}$.

\section{Read The Sensitivity Test of Gentamycin and CTX}

1. The sensitivity test to $\mathrm{HgCl}_{2}$ is said to be susceptible if the diameter of the zone of inhibition is $\geq 15 \mathrm{~mm}$, and resistant if $\leq$ $12 \mathrm{~mm}$.

2. The sensitivity test to Cefotaxime is said to be susceptible if the zone of inhibition is $\geq 26 \mathrm{~mm}$ and resistant if the zone of inhibition is $\leq 22 \mathrm{~mm}$

3. The ESBL screening test is said to be positive if it is resistant to Cefotaxime

\section{Reasearch Data Collection Procedures}

The research data collection procedure consisted of observing and recording the results of the observations into the table that had been provided.

\section{Data Processing and Analysis Techniques}

Processing techniques and data analysis were obtained statistically using Chi-square analysis.

\section{Result}

The samples of this study were 27 Escherichia coli isolates obtained from clinical specimens taken by consecutive sampling. Samples were collected from May 2019 to August 2019. E. coli isolates obtained from the phoenix automatic machine were retested using the KirbyBauer method, the results are in table 5.01. The re-sensitivity test using the KirbyBauer antibiotic disc diffusion method was carried out to equate the methods used during the screening test and ESBL confirmation.

All isolates that met the inclusionexclusion criteria were exposed to $\mathrm{HgCl}_{2}$ at concentrations of $0.02 \mathrm{ppm}, 0.10 \mathrm{ppm}, 0.20$ ppm, and Cefotaxime (CTX). The exposure was carried out every day in a petri dish containing Mueller Hinton Agar using $\mathrm{HgCl}_{2}$ with a concentration of $0.0 .02 \mathrm{ppm}$, $0.10 \mathrm{ppm}, 0.20 \mathrm{ppm}$ with a maximum length of research for 1 day. If within 1 day of the study a positive result of mercury resistance is obtained, then it will be continued by providing exposure to screen for ESBL.

The research was carried out using the Kirby-Bauer method, by dripping a blank disc with drops of $\mathrm{HgCl}_{2}$ with a concentration of $0.02 \mathrm{ppm}, 0.10 \mathrm{ppm}, 0.20$ ppm then a disc containing $\mathrm{HgCl}_{2}$ with a concentration of $0.02 \mathrm{ppm}, 0.10 \mathrm{ppm}, 0.20$ 
ppm was exposed on the surface of the $\mathrm{MH}$ agar plate. After being incubated for 24 hours, the results are in the following table. The basis for determining the concentration of mercury used in this study is based on research conducted by Natalia from Unair, which resulted in a mercury concentration of 1.22 ppm E. coli bacteria were still alive. So the researchers used mercury with a concentration of $0.02 \mathrm{ppm}, 0.10 \mathrm{ppm}$, and $0.20 \mathrm{ppm}$ in the hope that researchers would get results whether in an environment containing mercury with a concentration of $0.02 \mathrm{ppm}$ E. coli bacteria could still survive. This research technique uses the KirbyBauer method by dripping a blank disc with a concentration of $0.02 \mathrm{ppm}$ of $\mathrm{HgCl}_{2}, 0.10$ ppm, 0.20 ppm then a disk containing $\mathrm{HgCl}_{2}$ with a concentration of $0.02 \mathrm{ppm}, 0.10 \mathrm{ppm}$, $0,20 \mathrm{ppm}$ was exposed on the surface of the MH agar plate.

The method used is based on the direction of Edy Bagus who is a professor in Microbiology, Airlangga University, which is the result of his experience and research in Japan.

Table 1. E. coli Resistance To $\mathrm{Hgcl}_{2}$ Exposure With Consentration Of 0,02 Ppm ( $\mathrm{n}=9$ ), $0,10 \mathrm{ppm}(\mathrm{n}=9), 0,20 \mathrm{ppm}(\mathrm{n}=9)$ by kirbybauer method (total $n=27$ )

\begin{tabular}{cccc}
\hline No & \multirow{2}{*}{ Exposure } & \multicolumn{2}{c}{ Exposure Day - 1 } \\
\cline { 3 - 4 } & & Sensitivity & Resistance \\
\hline $\mathbf{1}$ & $\mathrm{HgCl}_{2} 0,02 \mathrm{ppm}$ & $0(0 \%)$ & $9(100 \%)$ \\
\hline $\mathbf{2}$ & $\mathrm{HgCl}_{2} 0,10 \mathrm{ppm}$ & $0(0 \%)$ & $9(100 \%)$ \\
\hline $\mathbf{3}$ & $\mathrm{HgCl}_{2} 0,20 \mathrm{ppm}$ & $0(0 \%)$ & $9(100 \%)$ \\
\hline
\end{tabular}

On the first day of exposure to $\mathrm{HgCl}_{2}$ using the Kirby-Bauer method using a blank disk that has been dripped with $\mathrm{HgCl} 2$ with a concentration of $0.02 \mathrm{ppm}, 9$ (100\%) resistant isolates were obtained, by exposure to $\mathrm{HgCl}_{2}$ with a concentration of 0.10 ppm obtained $9(100 \%)$ isolates that were resistant and by exposure to $\mathrm{HgCl}_{2}$ with a concentration of $0.20 \mathrm{ppm}$, obtained $9(100 \%)$ resistant isolates.

The next stage of the research was carried out using the results of the first treatment, by exposure to $\mathrm{HgCl} 2$ concentrations of $0.02 \mathrm{ppm}, 0.10 \mathrm{ppm}, 0.20$ ppm then exposed to the Cefotaxime disk as a screening for ESBL.

Tabel 2. E. coli Resistance to Cefotaxime post $\mathrm{HgCl}_{2}$ Exposure in 0,02 ppm ( $\left.\mathrm{n}=9\right), 0,10$ $\operatorname{ppm}(\mathrm{n}=9), 0,20 \mathrm{ppm}(\mathrm{n}=9)$ Consentration with Kirby-Bauer Method (total =27)

\begin{tabular}{cccc}
\hline \multirow{2}{*}{ No } & \multirow{2}{*}{ Exposure } & \multicolumn{2}{c}{ Exposure Day - 1 CTX } \\
\cline { 3 - 4 } & & Sensitivity & Resistance \\
\hline $\mathbf{1}$ & $\mathrm{HgCl}_{2} 0,02 \mathrm{ppm}$ & $3(33,3 \%)$ & $6(66,7 \%)$ \\
\hline $\mathbf{2}$ & $\mathrm{HgCl}_{2} 0,10 \mathrm{ppm}$ & $0(0 \%)$ & $9(100 \%)$ \\
\hline $\mathbf{3}$ & $\mathrm{HgCl}_{2} 0,20 \mathrm{ppm}$ & $2(22,2 \%)$ & $7(2,8 \%)$ \\
\hline
\end{tabular}

On the first day of exposure to Cefotaxime on the results of $0.02 \mathrm{ppm}$ $\mathrm{HgCl} 2$ exposure, 3 (33.3)\%) isolates were still susceptible to Cefotaxime and 6 $(66.7 \%)$ isolates were resistant to Cefotaxime. On the first day of exposure to Cefotaxime on the results of exposure to $\mathrm{HgCl} 20.10 \mathrm{ppm}$, there were no $(0 \%)$ isolates that were still susceptible to Cefotaxime and $9(100 \%)$ isolates that were resistant to Cefotaxime. On the first day of exposure to Cefotaxime on the results of exposure to $\mathrm{HgCl} 20.20$ ppm, 2 (22.2)\%) were still susceptible to Cefotaxime and 7 $(77.8 \%)$ isolates were resistant to Cefotaxime.

All isolates from $E$. coli became resistant after exposure to $\mathrm{HgCl}_{2}$ with concentrations of $0.02 \mathrm{ppm}, 0.10 \mathrm{ppm}, 0.20 \mathrm{ppm}$ on the first day of exposure. There was no difference between exposure to $\mathrm{HgCl}_{2}$ with a concentration of $0.02 \mathrm{ppm}, 0.10 \mathrm{ppm}, 0.20$ ppm. In efotaxime exposure to the emergence of ESBL in Escherichia coli from urine specimens, different results were obtained at each $\mathrm{HgCl}_{2}$ concentration previously exposed. 


\section{Discussion}

In this study, 27 isolates were exposed to $\mathrm{HgCl} 2$ with a concentration of $0.02 \mathrm{ppm}(9$ isolates), $0.10 \mathrm{ppm}$ (9 isolates), $0.20 \mathrm{ppm}$ (9 isolates), it was found that all E. coli isolates from urine were resistant $E$. coli. mercury. This is following research conducted by Hinonaung (2013) from the Chemistry Section of the Faculty of Medicine, Sam Ratulangi University. The research was carried out in several stages, mentioned the isolation stage of mercury resistant bacteria which aims to isolate the bacteria present in tartar, urine, and fecal samples. The results obtained from 6 isolates found four types of mercury-resistant bacteria in tartar sediment, feces, urine, there are Enterococcus, Bacillus sp, Streptococcus $s p, E$. coli. The results of the resistance test to mercury showed that 3 bacteria can survive up to a $40 \mathrm{ppm} \quad \mathrm{HgCl} 2$ concentration, namely Enterococcus, Bacillus sp, and Streptococcus sp. At a concentration of $20 \mathrm{ppm}$ of Phenyl Mercury, 2 bacteria can survive, namely Bacillus sp, E.coli (Hinonaung, 2013).

In this study, $\mathrm{HgCl} 2$ was used with a small concentration of $0.02 \mathrm{ppm}$ to prove that with a very small concentration, E. coli had adapted and became mercury resistant. Heavy metal contamination, including mercury in humans, will continue to increase in line with the increasing exploitation of various natural sources where heavy metals are contained. This is related to the properties of heavy metals:

1. Difficult to degrade, so that problems accumulate in the aquatic environment and its natural presence is difficult to decompose.

2. Can accumulate in organisms and will endanger the health of humans who consume these organisms.
3. Easily accumulates in sediments, so that the concentration is always higher than the metal concentration in water. Besides, sediment is easily suspended by the movement of water masses which will dissolve the metal it contains back into the water so that the sediment becomes a potential source of pollution in a certain time scale.

Humans are exposed to heavy metals, such as mercury because the properties of heavy metals above will cause them to have mercury levels in their bodies (Widowati et al., 2008). So that the bacteria that are in the human body will be in an environment that contains mercury. Bacteria that live in environments exposed to mercury will try to defend themselves by detoxifying mercury so that these bacteria can live in environments that contain mercury. Bacteria that try to defend themselves from exposure to mercury in the environment will experience a change in their genes to become mercury-resistant bacteria.

Mercury detoxification by mercuryresistant bacteria occurs because bacteria have the mer operon gene. The structure of the operon mer is different for each type of bacteria. Generally, the operon mer structure consists of the metalloregulator gene (merR), the mercury transfer gene (merT, merP, merC), the mercury reductase gene (merA), and the organo mercury lyase (merB). Protein The merA gene is the gene responsible for the presence of the enzyme mercury reductase. The mercury reductase enzyme will give 2 electrons to NADPH or NADP so that $\mathrm{Hg} 2$ + turns into $\mathrm{Hg} 0$ which is volatile and will be removed from the cell (Brown et al, 2002), while the MerB protein has the function of catalyzing the breaking of the mercury-carbon bond resulting in organic compounds and $\mathrm{Hg} 2+$ ions. (Barkay et al., 2003). 
However, there is another possibility besides the allegations above is that $E$. coli that enters the human body is already an $E$. coli bacteria that are already resistant to mercury. This requires further research to prove the truth of the allegations above regarding the presence of mercury-resistant $E$. coli bacteria found in the body of this research sample.

The results of the first stage were $E$. coli bacteria that had been exposed to $\mathrm{HgCl} 2$ with a concentration of $0.02 \mathrm{ppm}, 0.10 \mathrm{ppm}$, $0.20 \mathrm{ppm}$ which turned out to be all mercury resistant, then the mercury-resistant $E$. coli bacteria were exposed to Cefotaxime discs for ESBL screening. Previously, Cefotaxime was exposed to E. coli on the primary plate and the results were all are Cefotaxime susceptible E. coli. After that, the E. coli from the primary plate was exposed to mercury with a concentration of $0.02 \mathrm{ppm}, 0.10 \mathrm{ppm}, 0.20 \mathrm{ppm}$, then the results of the previous exposure were exposed to Cefotaxime discs for ESBL screening. The results of changes in the phenotypic properties of several non-ESBL E. coli isolates became ESBL after being exposed to Cefotaxime on the first day.

On the first day of exposure to Cefotaxime on the results of $0.02 \mathrm{ppm}$ $\mathrm{HgCl} 2$ exposure, 3 (33.3)\%) isolates were still susceptible to Cefotaxime and 6 $(66.7 \%)$ isolates were resistant to Cefotaxime. On the first day of exposure to Cefotaxim on the results of exposure to $\mathrm{HgCl} 20.10 \mathrm{ppm}$, there were no $(0 \%)$ isolates that were still susceptible to Cefotaxime and $9(100 \%)$ isolates that were resistant to Cefotaxime. On the first day of exposure to Cefotaxime on the results of exposure to $\mathrm{HgCl} 20.20$ ppm, 2 (22.2)\%) were still susceptible to Cefotaxime and 7 $(77.8 \%)$ isolates were resistant to Cefotaxime.
This is consistent with research conducted by Ayu (2013) from the Biology Department, Faculty of Mathematics and Natural Sciences, Hasanuddin University, Makassar. In her research, the isolation of bacteria from seawater samples from Losari Beach was carried out using nutrient agar for Synthetic Seawater (NA ALS) media with added mercury at a concentration level of $0.02 \mu \mathrm{g} / \mathrm{ml}$. Then the bacterial isolates were tested for antibiotic resistance using antibiotic paper disks (Oxoid) including

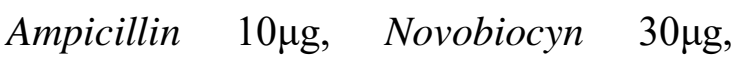

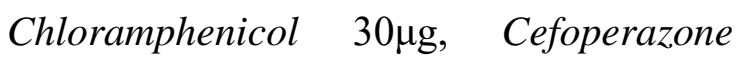
$75 \mu \mathrm{g}$, and Ofloxacin 5 $\mathrm{g}$. Three types of isolates are resistant to mercury $(\mathrm{Hg})$ and the antibiotics obtained are: mercury I resistant bacteria isolates which are also

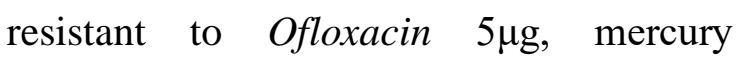
resistant bacteria II isolates that are resistant to Ampicillin $10 \mu \mathrm{g}$ and mercury III resistant bacteria isolate that is resistant to all types of antibiotics.

In plasmids or transposons, it may also stimulate the formation of genes coding for resistance to several antibiotics, one of which is in the enzyme-producing bacteria ESBL, where ESBL is mostly derived from TEM and SHV enzymes, and in lesser amounts than CTX (Walker et al., 2015) where ESBL coding genes can be chromosomal or plasmidal. The resistance mechanism of each class of antibiotics can be different from other groups. Some researchers mention cross-resistance between different antibiotic classes (Canton and Coque, 2006; Talan et al., 2016). Changes in E. coli which are initially sensitive to non-ESBL mercury, but because living in an environment that has high mercury levels can changes it to ESBL mercury-resistant E. coli (Chojnacka, 2010) 


\section{Conclusion}

The E. coli bacteria in the urine in sample body is mercury-resistant $E$. coli. This is proved by the results of exposure to mercury with concentrations of $0.02 \mathrm{ppm}$, $0.10 \mathrm{ppm}, 0.20 \mathrm{ppm}$. It was found that all 30 samples of the study were mercury-resistant E. coli. Exposure to Cefotaxime for 1 day by invitro to mercury-resistant $E$. coli isolates non ESBL caused changes in $22 E$. coli isolates in the urine. This proves that exposure to $\mathrm{HgCl} 2$ with various concentrations to $E$. coli isolates can accelerate the phenotic change from nonESBL E. coli to ESBL E. coli.

\section{References}

Barkay, T., S.M. Miller, A.O. Summers. 2003. Bacterial Mercury Resistance from Atoms to Ecosystems. FEMS Microbiol. Rev. 27:355-384.

Boyd, Eric S., Tamar Barkay. 2012. The mercury resistance operon: from an origin in a geothermal environment to an efficient detoxification machine. Frontiers in Microbiology. Published October 2012. Accessed from https://www.frontiersin.org/articles/10.3 389/fmicb.2012.00349/full.

Brown, N., Shih, Y., Leang,C., Glendinning, K., Hobman, J \& Wilson, J. 2002. Mercury transport and resistance Biometals, Internasional Biometals Symposium

Cantón R, Coque TM, 2006, The CTX-M beta-lactamase pandemic, Servicio de Microbiología, Hospital Ramón y Cajal, 28034-Madrid, Spain.

Chojnacka K , 2010, Biosorption and bioaccumulation--the prospects for practical applications, 36(3):299-307. doi: 10.1016/j.envint.2009.12.001. Epub 2010 Jan 6, Diakses tgl 20 Januari 2017.

Hinonaung Hamonangan Jefry, Bodhi Widdhi, KepelI Billy, 2013, Identifikasi
Bakteri Resisten Merkuri Pada Individudi Daerah Pesisir Pantai Di Desa Budokecamatan Wori, Bagian Kimia Fakultas Kedokteran Universitas Sam Ratulangi.

Palar, H. 2008. Pencemaran dan Toksikologi Logam Berat. Rinekacipta : Bandung. Republika.

Ririn,Ayu Dwi. 2013. Isolasi Dan Uji Resistensi Antibiotik Bakteri. Resistensi Merkuri ( $\mathrm{Hg}$ ) Dari Kawasan Pantai. Losari Makassar, Jurusan Biologi, Fakultas Matematika dan Ilmu Pengetahuan Alam Universitas Hasanuddin Makasar.

Saraswati, D., Fahruddin. 2012. Uji Resistensi Antibiotik pada Bakteri Resisten Merkuri (Hg) yang di Isolasi dari Kawasan Pantai Losari Makassar Test of Antibiotic Resistance in Bacteria Resistant Mercury $(\mathrm{Hg})$ in Isolation from Makassar Losari Region, Jurusan Biologi, Fakultas Matematika dan Ilmu Pengetahuan Alam Universitas Hasanuddin

Talan DA, Takhar SS, Krishnadasan A, Abrahamian FM, 2016. Fluoroquinolone-Resistant and Extended-Spectrum $\quad \beta$-LactamaseProducing Escherichia coli Infections in Patients with Pyelonephritis, United States. Emerging Infectious Diseases 22(9); 1594-604

Walker KE, Mahon CR, Lehman D, Manuselis G, 2015. Enterobacteriaceae. InText book of diagnostic microbiology $5^{\text {th }}$ ed. pp 420-54

Widowati W., Astiana S. dan Raymond J.R., 2008, Efek Toksik Logam, Pencegahan dan Penanggulangan Pencemaran. Penerbit ANDI, Yogyakarta 